\title{
Financial Performance Measurement Model Modification Using Tools of Ritchi Kolodinsky and International Standard Zakat of Management (ISZM)
}

\author{
Peny CahayaAzwari, Nurfala Safitri, Rambo Saputra \\ State Islamic University of Raden Fatah Palembang \\ Khairul Rijal (Corresponding Author) \\ International Islamic University of Malaysia (IIUM) \\ Paper to be presented at International Conference of Zakat 2019 \\ 3-4 October, Universitas Padjadjaran, Bandung, Indonesia
}

\begin{abstract}
The effectiveness and efficiency in a nonprofit organization have different meanings than in profit-orientated organizations. This study aims to see how the financial effectiveness and efficiency was analyzed based on its social impact and sustainability of the program. The research is based on a sample of nonprofits, chosen from the database of the website published on the panel data provided by their financial statements. The financial effectiveness and efficiency are calculated, using the ratios method modification from Ritchie and Kolodinsky model compared to International Standard Zakat of Management (ISZM), by reporting the realized elements to the targeted ones. The period of our analysis involves six fiscal years for the chosen sample. The results of this study involve measures of financial effectiveness and efficiency for each entity studied. The studied in the period identify factors which influence both effectiveness and efficiency and its evolution and interpreting the results for the whole field.
\end{abstract}

Keywords: Performance measurement, social impact, nonprofit organization.

\section{INTRODUCTION}

Indonesia a majority Moslem population in the world with the potential of zakat increasing every year. Based on data from the National Zakat Board (BAZNAS) shows that the potential of zakat funds in Indonesia by 2011 amounted to $\mathrm{Rp} 217$ trillion. Architecture Zakat Indonesia said that zakat potential is growth targeted of $30 \%$ so that in 2018 the Fundrising of zakat rose to $\mathrm{Rp}$ 8.7 Trillion (2018: 78). Potential zakat Fundrising may reach $3.4 \%$ or $\mathrm{Rp} 462$ trillion in 2017 from the total GDP if the charity set up as a tax deduction (Sudibyo, 2018). The magnitude of this potential has not be realized optimally. In 2017, the amount of zakat, infaq, and sadaqah (ZIS) collected amounted to 6.2 trillion (BAZNAS, 2018). An increase of about $24 \%$ of the Fundrising of ZIS in 2016, amounting to 5 trillion (PUSKAS BAZNAS, 2017 ) is relatively small compared to the potential zakat Fundrising. Percentage growth of zakat Fundrising also showed a decline in 2016 amounted to $37,34 \%$ to $24.06 \%$ in 2017. 
Table 1. Potential Zakat Fundrising

\begin{tabular}{|c|c|c|c|c|c|c|}
\hline \multirow{2}{*}{ Year } & \multirow{2}{*}{$\begin{array}{c}\text { Potency } \\
\text { Trillion (T) }\end{array}$} & \multirow[b]{2}{*}{ Realization } & \multicolumn{2}{|c|}{ Percentage (\%) } & \multicolumn{2}{|c|}{ Percentage (\%) } \\
\hline & & & \% Realization & \% Growth & Distribution & \% Distribution \\
\hline 2010 & $217 \mathrm{~T}$ & $1.5 \mathrm{~T}$ & 0.7 & 25 & & \\
\hline 2011 & $217 \mathrm{~T}$ & $1,729 \mathrm{~T}$ & 0.8 & $15: 27$ & & \\
\hline 2012 & $217 \mathrm{~T}$ & $2,212 \mathrm{~T}$ & 1 & 27.94 & & \\
\hline 2013 & $217 \mathrm{~T}$ & $2,639 \mathrm{~T}$ & 1.2 & $19: 30$ & & \\
\hline 2014 & $217 \mathrm{~T}$ & $3.3 \mathrm{~T}$ & 1.5 & 5.25 & & \\
\hline 2015 & $286 \mathrm{~T}$ & $3.653 \mathrm{~T}$ & 1.7 & 10.71 & $2.25 \mathrm{~T}$ & \\
\hline 2016 & $440 \mathrm{~T}$ & $5.017 \mathrm{~T}$ & 1 & 37.34 & $2.93 \mathrm{~T}$ & 58.42 \\
\hline 2017 & $462 \mathrm{~T}$ & $6.2 \mathrm{~T}$ & & 6.24 & $4.86 \mathrm{~T}$ & 65.81 \\
\hline 2018 & $\mathrm{Na}$ & $\mathrm{Na}$ & $\mathrm{Na}$ & $\mathrm{Na}$ & & \\
\hline 2019 & $\mathrm{Na}$ & $\begin{array}{c}10.5 \mathrm{~T} \\
\text { (Projection) }\end{array}$ & $\mathrm{Na}$ & $\mathrm{Na}$ & & \\
\hline
\end{tabular}

Source: Author's Computations

Table 2. The National Raising Funds by Type

\begin{tabular}{|c|c|c|c|c|c|c|c|}
\hline $\begin{array}{l}\text { Type of } \\
\text { Fund }\end{array}$ & 2013 & 2014 & 2015 & 2016 & $\%$ & 2017 & $\%$ \\
\hline $\begin{array}{l}\text { Zakat Maal- } \\
\text { Income } \\
\text { Individuals }\end{array}$ & 23.320.146.044 & 117.085731 .136 & 2.217 .083 .240 .925 & 2.843.695.144.686 & 56.68 & 2.785.208.957.779 & 44.75 \\
\hline $\begin{array}{l}\text { Zakat Maal- } \\
\text { Corporate }\end{array}$ & & & & 620.546547 .627 & 12.37 & 307.007.314.242 & 4.93 \\
\hline $\begin{array}{l}\text { Zakat Fitrah } \\
\text { Ramadhan }\end{array}$ & & & & 273.975.100.183 & 5.46 & 1.101 .926 .162 .357 & 17.70 \\
\hline $\begin{array}{l}\text { Infaq/ } \\
\text { Sadaqah } \\
\text { Individual }\end{array}$ & 15.353.101.220 & 23.499.642.443 & 613.903.803.762 & 858.631 .089 .706 & 17.11 & 1.651 .254 .048 .632 & 26.53 \\
\hline $\begin{array}{l}\text { Infaq/ } \\
\text { Charity/ } \\
\text { CSR/ PKBL } \\
\text { Board } \\
\end{array}$ & & & & 142.867 .215 .300 & 2.85 & 113.629 .148 .360 & 1.83 \\
\hline $\begin{array}{l}\text { Other } \\
\text { Religious } \\
\text { Social Fund } \\
\text { (DSKL) }\end{array}$ & & & & 277.336 .514 .452 & 5.53 & 265.345.638.101 & 4.26 \\
\hline Other funds & & & & 241.514 .997 & 0.00 & 0 & 0,00 \\
\hline TOTAL & & & & 5.017 .293 .126 .950 & 100 & 6.224 .371 .269 .471 & 100 \\
\hline
\end{tabular}

Source: Author's Computations

Table 2 illustrates the reduction in the quantity types of zakat both in individual andcorporate as the main source of fund from theNational Zakat Board (BAZNAS) and National Zakat Institution LAZNAS. The increasing in zakat sector as the main 
source of zakat is not visible. This may reflect income levels and declining public confidence. Potential of zakat corporatehas decreased, it shows that is not optimal in the funding sector. Based on the distribution by ashnaf, the amount of funds has distributed by ashnaf 2017 .

Table 3. Distribution based on Ashnaf

\begin{tabular}{lcccc}
\hline \multirow{2}{*}{ Ashnaf } & \multicolumn{1}{c}{ Year 2016 } & \multicolumn{2}{c}{ Year 2017 } \\
\cline { 2 - 5 } & Amount of funds & \% & Amount of funds & \% \\
\hline Poor people & 2.137 .613 .944 .379 & 72.93 & 3.356 .325 .642 .451 & 69.06 \\
\hline Amil & 209.233 .041 .289 & 7.14 & 518.647 .467 .254 & 10.67 \\
\hline Muallaf & 17.403 .367 .642 & 0.59 & 97.156 .889 .988 & 2.00 \\
\hline Riqob & 4.278 .727 .729 & 0.15 & 21.827 .062 .720 & 0.45 \\
\hline Gharimin & 16.435 .575 .105 & 0.56 & 40.772 .744 .732 & 0.84 \\
\hline Fi Sabili'llah & 524.865 .496 .303 & 17.91 & 755.062 .496 .814 & 15.54 \\
\hline IbnuSabil & 21.379 .958 .163 & 0.73 & 70.363 .020 .484 & 1.45 \\
\hline Total & 2.931 .210 .110 .610 & 100 & 4.860 .155 .324 .445 & 100 \\
\hline
\end{tabular}

Source: BAZNAS (2018)

Table 3 shows the largest percentage of the receiver ashnaf group ispoor people then fi sabilillah. The lowest percentage for 2 years is riqob. The percentage of each recipient ashnaf did not align on priority targets so that Fi sabilillah group including the second largest percentage of beneficiaries. The largest percentage of poor people also demonstrated severalof Indonesia's populations is under the poverty line. Increasing the quantity of the amount of zakat distribution for ashnaf is fair along with increased had kifayah and the community poverty line. This increase should be well aligned with the reduction of poverty. It is inversely proportional when compared to the impact assessment of zakat to mustahik using welfare index BAZNAS through CIBEST Welfare Index, IPM modification, and independence index showing the results of an increase of 0.76 (Good) in 2018, an increase of 2017 amounted to 0.71 (Good). Research shows poverty reduction mustahik.

Table 4. Distribution based on sector

\begin{tabular}{|c|c|c|c|c|c|c|}
\hline \multirow{2}{*}{ Program } & \multicolumn{2}{|l|}{2016} & \multicolumn{3}{|c|}{2017} & \multirow{2}{*}{$\begin{array}{c}\text { Averag } \\
(\%)\end{array}$} \\
\hline & Total Distribution & $\%$ & Total Distribution & $\%$ & Total Mustahik & \\
\hline Economy & 493.075.489.398 & 18.30 & 882.515 .274 .729 & 20.33 & 1.088 .758 & 19.31 \\
\hline Education & 842.980 .341 .134 & 31.28 & 941.865 .099 .137 & 21.69 & 1.544 .611 & 26.48 \\
\hline Dakwah & 418.454 .281 .897 & 15.53 & 979.468 .717 .694 & 22.56 & 3.980 .188 & 19.04 \\
\hline Health & 226.004 .399 .823 & 8.39 & 413.507 .938 .849 & 9.52 & 365.829 & 8.95 \\
\hline $\begin{array}{l}\text { Social and } \\
\text { Humanita- } \\
\text { rian }\end{array}$ & 714.267 .956 .361 & 26.51 & 1.124 .150 .826 .782 & 25.89 & 1.753 .646 & 26.20 \\
\hline TOTAL & 2.694 .782 .468 .613 & 100 & 4.341 .507 .857 .190 & 100 & 8.733 .032 & 100 \\
\hline
\end{tabular}

Source: BAZNAS (2019) 
Table 4 shows the distribution of the field fluctuations that undergo significant changes. 2016, the distribution of education reached $31.28 \%$ but decreased in 2017 by $21.69 \%$. Economic sector increased from 18:30 becomes 20:33\% 2016\% 2017 highest percentage is in the field of social humanity $26.51 \% 201625.89 \%$ decline in 2017. The health sector also increased from 8:39 in 2016 become\% 9:52\% in 2019. Overview field distribution is a concern because the percentages illustrate the main function of zakat institution in alleviating poverty. The proportion of distribution between field changes proportionally.

When compared with the proportion of mustahik are increasing every year, demonstrating the effectiveness of programs to alleviate poverty BAZNAS yet achieved optimally. By comparing the increase in the number of distributions, and the increase in the number of mustahik patterns show that the effectiveness of the program has not run optimally BAZNAS.

Based on the Fundrising and distribution of OPZ in 2017, over half the national Fundrising and distribution of managed BAZNAS district/city. With the amount of 500 and reach almost all regencies and cities in Indonesia, BAZNAS district/city managed to collect ZIS by nearly 3.5 trillion rupiahs and distributed more than 2.5 trillion rupiahs in 2017. When compared with the number of units BAZNAS city/district 500 is not proportional, since reached only $3.5 \mathrm{~T}$ and BAZNAS province with the number 34 , is only able to collect $450 \mathrm{M}$ while the national scale BAZNAS able to reach $153 \mathrm{M}$.

National Zakat Institution (LAZNAS), which consists of LAZ national, province, and district/city managed to raise more than 2 trillion rupiahs and distributed more than 1.7 trillion rupiahs in the same year. There are 34 BAZNAS Province managed to collect nearly 450 billion rupiahs and distributed more than 380 billion rupiahs, while the central BAZNAS managed to raise more than 150 billion rupiahs and distributed more than 130 billion rupiahs. In 2017, the cumulative total fund reached more than 6.2 trillion rupiahs by the number of distribution of more than 4.8 trillion rupiahs. National absorptive capacity reached $78.08 \%$, which shows that the absorption of funds in 2017 is "effective". Compared with the previous year, the rate of absorption is increased by $19.66 \%$ compared to absorption in the previous year. BAZNAS, BAZNAS Province, BAZNAS district/city, and LAZ also have high levels of absorption over $70 \%$ so that the category of "effective". The amount of absorption is not able to show the true performance of OPZ because just look at the distribution level comparison with the Fundrising in the aggregate and not in proportion.

LAZ is BAZNAS synergistic partners in zakat management as envisaged by Law No. 23, 2011. Each OPZ has models vary, but in terms of the distributionutilization, BAZNAS and LAZ have the same number of field distribution which consists of five groups, namely education, health, economic, social and dakwah. Badan Amil Zakat Nasional (BAZNAS) plays a role in poverty alleviation programs in Indonesia. A total of 18 percent or 4.5 million poor people have benefited from the program in the period 2016 BAZNAS Poverty reduction is an excellent program BAZNAS poor through community development programs based charity like Zakat for Community Development (ZCD). ZCD programs empower poor communities to develop their economies, for example, BAZNAS has facilitated the poor in Borneo to cultivate papaya mini. BAZNAS National Coordination Meeting in 2017 also has passed a resolution to eradicate poverty $1 \%$ per year, so the potential to alleviate poverty 
as much as 280,000 people or $1 \%$ of the number of poor people in Indonesia every year.

As an institution of zakat which is mandated by the state as stipulated in Law No.23 of 2011 on Management of Zakat, BAZNAS and LAZ should be able to show a good performance, one's financial performance. Jumingan mention financial performance is a picture of the achievements in its operations, both related to financial aspects, marketing, Fundrising and distribution of funds, technology, and human resources.

Smalskys (2010) states that the public sector should be understood as the system of organization managing and using State resources. Arimaviciute (2005) states that "the public sector is the combination of public and private elements". The public sector is a totality of institutions, the which are supported from the State and municipal budgets, and It provides public goods, the which are not under any competition, and roommates accessible to any individual. The objective of the performance measurement system is to measure and assess quantitatively the degree achievement of set goals and tasks. It is possible to state that the performance measurement system has two functions play to provide information that would allow improving the performance of organizations in the public sector and to account for the funds used Baboniene and Vecerskienen (2015: 314).

Atalay et.al (2017: 180-193) said measuring the financial performances of the nonprofit organization provides financial information about the organization to the decision makers that how successfully, Effectively, and productivity they were managed from the Financial Data and should be prepared in accordance with this analysis. This is reinforced by Ramadan and Borgonovi (2015); Balaboniene and Vecerskienen (2015: 314) suggest measuring the performance is a vital mechanism to maximize social impact and achieving the objectives of NGOs through a complex combination of performance measurement methods known in the business sector and applied in the public sector.

Measuring the performances of the nonprofit organization can be based on the real Data roommates are taken from them. A Nonprofit organization can be rated based on their financial performances. This organization may have better opportunities grade up to reviews their performance.

\section{RESEARCH METODHOLOGY}

\section{Shariah Enterprise Theory (SET)}

Sharia Enterprise Theoryby Triyuwono (2012) is the basis of the development of several theories that proprietary theory, Entity Theory and Enterprise Theory. Proprietary concept theory puts the owner as of the center of all interests that lead to consequences of stimulation legitimacy and selfish behavior, and individuals in business behavior. The proprietary concept expresses a hierarchy of power theory of wealth is centralized, totalitarian and potentially even lead to a replica of a social war, with the form of an interactive competency increase the intensity of the urge for wealth. Entity Theory emerged to reduce the weaknesses of the proprietary theory. The business unit into the limelight that should be served, rather than the owner. Conceived entities have a separate existence implicitly or explicitly.

Shariah Enterprise Theory mentions stakeholders include three parts: God, Human Natural Shariah enterprise theory not sitting man as the center of everything but put God at the center of everything. God be the center point of the return of the man and the universe. Therefore, people here just as His 
representative (khalifatullah fil ard) which has consequences obedient to all of God's laws. Compliance man and (nature) solely to return to God with a quiet soul. The process of returning to God requires a process of union with their fellow human beings and nature as well as with the laws inherent in it.

The most important underlying axiom shariah enterprise theory that any determination of the concept is of God as Creator and Owner Single from all resources that exist in this world. That applies in the enterprise theory is God's sharia as the main source, because he is the sole owner and the absolute of all the existing resources in the world. Resources owned by all stakeholders, in principle, is the mandate of God in it attached a responsibility to use the means and goals set by the Giver of Amanah (Surah Al-Baqarah: 254 \& 267).

Economic practice in zakat institution should establish humane human behavior (ethics) that strengthen selfawareness (self-consciousness) of nature (fitrah) of the man himself. All the activities are not purely secular (worldly) but having a form of accountability vertically or horizontally as a form of worship (worship) to God in real terms actualized in the form of activities creating and spreading prosperity to all the worlds.

\section{Organizational Theory}

Organization theory is a way to view and analyze the organization more accurate and in-depth. How to see and think about the organization based on the pattern and regularity, organize, measure it, and make it readily available to run (Daft, 2007). Jones (2013) mentions organizational theory is the study of how organizations function and how the organization influences and is influenced by the internal and external environment in which organizations operate. The concept is based on both the organizational theory in this study show an accurate and deep study of the patterns and regularities, to the arrangement of the internal components of the organization so that the organization can function, as well as how the organization affects and is affected by the component and those that exist in the organization.

The organization's internal environment includes elements of human resources work and other resources within the organization. The development of the organization depends on the people who work in it that defines the direction and goals of the organization in accordance with the changing environment. Based on the theory of the organization, the research will focus on models of interaction between the internal elements that the financial performance of zakat management organizations.

\section{Performance Measurement}

The concept of performance defined as demonstrated ability to acquire resources for organizational survival necessary including annual Increase of revenues, inflows, and net surplus of financial resources. (Kanter and Summers, 1987; Kendall and Knapp, 2000) has been in the highlight of academic research over the last two dsecades. This was confirmed from the results of research Polese et al (2017) states that business performance is as a useful tool for practitioners (manager of a public organization) and scholars (professors, researchers, and students for adequate management of performance measures. One particular aspect of performance is the Appropriate yardstick with roommates to measure or assess the performance of NPOs (Herman and Renz, 1999; Gill et al., 2005; Aldrick, 2009).

Prominent internal factors include a variety of financial indicators such as fundraising efficiency (Aldrick: 2009) absence of repeated financial deficits, cost 
and growth positions and fiscal performance (Ritchie and Kolodinsky 2003; Gill et al., 2005). Aldrick (2009) finds the cost of fundraising and its effectiveness as an important measure of performance in UK charities.

\section{Zakat Institutions Performance Measurement}

World Zakat Forum \& Indonesia Magnificence of Zakat (2017) emphasized the importance of the financial performance for the institution of zakat to measure the efficiency of fund management and institutional accountability zakat and explore the use of funds in the run-owned distribution program. When the zakat institution can not efficiently manage the fund, will have an impact on the reduction of trust muzaki to pay zakat. Each type of organization using analytical tools and methods of measurement of certain financial performance tailored to the relevant needs to be applied (Romantin, Bahri, \& Lopez, 2017).

Financial performance measurement is aimed at analyzing the financial performance of zakat institution in one period using a measuring instrument or specific analysis tools as appropriate. Ratio analysis is a common method that is used for measuring fiscal performance. Nevertheless, its use in a nonprofit organization is fairly limited. Some of the ratios used for the companies are not directly related to the nonprofit organization targets because of the differences. (Atalay, Gungormus, and Ender, 2017: 180-193).

In general, NGOs can assess reviews their performance by creating performance indicators and then gathering information related to these indicators. Carman (2007) saw that the most utilized performance indicators by NGOs incorporate efficiency, effectiveness, fundraising, costs, audits, and beneficiaries' satisfaction. Teelken (2008) used four performance indicators to Evaluate NGOs operations: efficiency, effectiveness, economy, and efficacy. Similarly, Fine and Snyder (1999) stressed that performance measurement in NGOs includes identifying and assessing indicators roommates mainly address efficiency and effectiveness.

Considering the financial performance of NGOs, fundraising efficiency is the main variable that has been heavily Mentioned and highlighted in the literature. Andreasen and Kotler (2008) defined as a fundraising efficiency Process of Obtaining funds for NGOs survival. The fundraising efficiency is measured using donors dependency ratio (Epstein and McFarlan, 2011). Lewis (2009) Also Mentioned that the resource generation ratio is another measure used to Evaluate fundraising efficiency. Other measures such as the number of funding costs and the response rate of funding proposals are used also for evaluating fundraising efficiency (Niven, 2008).

\section{Financial Performance Model Ritchie \& Kolodinsky}

Each type of technical analysis company uses financial performance measures that are tailored to the needs and the types of tools relevant measure to be applied. Financial performance measurement can be made to charity organizations, as was done to the nonprofit. Because basically, zakat institution is part of a nonprofit organization that is not oriented towards profit.

1. The ratio of public support is a ratio used to measure how much of the proceeds OPZ of public support. Through this ratio can be known whether OPZ an institution that relies on voluntary donations or be able to independently raise funds through 
fundraising programs it has. Components of the group this ratio is:

a. Total contribution (TC)/ Total Revenue

b. Total contribution (TC)/ Total Cost

Information:

TC (Total Contribution) $=$ Total revenue from voluntary funds

2. Fundraising efficiency ratio (fundraising efficiency) is a ratio used to measure how efficient use of funds disbursed to finance the implementation of the fund-raising activities (such as advertising costs, campaigns, and socialization). This ratio is the ratio between the total fee income to raise funds. The formula for computing this ratio as follows:

Information:

FE (Fundraising Expense) $=$ Total cost of fund (dissemination and publication)
Financial Performance Model International Standard of Zakat Management (ISZM)

Measurement of financial performance in the International Standard zakat institution of Zakat Management (ISZM) consists of measuring the efficiency of zakat institution and the measure of the capacity of the organization. The efficiency component measurements will show whether the management of funds by charity organizations has been efficient or not. Zakat institution is said to be efficient if a small charge to get the fundraising effort which must be in line with the programs and services of zakat institution (PEBS FEUI \& IMZ, 2010). Expenditures incurred zakat institutions should be more widely used for programs and services.

Zakat management efficiency can be measured by the ratio of program expenses, operating expense ratio, expense ratio mobilization and Fundrising efficiency (World Zakat Forum and Indonesia Magnificence of Zakat, 2017). Program load ratio obtained by dividing the total cost of the program with a total cost of zakat institution for one year. Cost of the program is meant spending aimed at empowering mustahik. So it will look great comparisons for running the program with the total expenditure. The bigger, the better the results.

Table 5. Variable Operationalization Financial Performance Measurement by ISZM

\begin{tabular}{|c|c|c|}
\hline Indicator & Formula & Information \\
\hline \multicolumn{3}{|c|}{ Variable Efficiency } \\
\hline \multirow{2}{*}{$\begin{array}{l}\text { Program Expense Ratio. } \\
\text { Juwaini (2015) }\end{array}$} & $P E$ & $P E=$ Program Expense \\
\hline & $\overline{T E}$ & $T E=$ Total Expense \\
\hline \multirow{2}{*}{$\begin{array}{l}\text { rating Expense Ratio. } \\
\text { 'aini (2015) }\end{array}$} & $O E$ & $O E=$ Operational Expense \\
\hline & $\overline{T E}$ & $T E=$ Total Expense \\
\hline \multirow{2}{*}{$\begin{array}{l}\text { Idraising Expense Ratio. } \\
\text { raini (2015) }\end{array}$} & $F E$ & $F E=$ Fundraising Expense \\
\hline & $\overline{T E}$ & $T E=$ Total Expense \\
\hline \multirow{2}{*}{$\begin{array}{l}\text { Fundraising Efficiency Ratio. } \\
\text { Juwaini (2015) }\end{array}$} & $F E$ & $F E=$ Fundraising Expense \\
\hline & $\overline{T C}$ & $T C=$ Total Contribution \\
\hline
\end{tabular}




\begin{tabular}{lll}
\hline \multicolumn{1}{c}{ Indicator } & Formula & \multicolumn{1}{c}{ Information } \\
\hline Growth of Reception Ratio & $\frac{P R n-P R n-1}{P R n-1}$ & $P R N=$ Primary Revenue (Main Reception) \\
(WZF \&IZM 2017). & $P R N-1=$ Primary Revenue (Main Reception) \\
\hline Growth of Program Expenses Ratio & $\frac{P E n-P E n-1}{P E n-1}$ & $P E N=$ Primary Expense (Load Program) \\
\cline { 2 - 3 } (WZF \&IZM 2017). & $\frac{W C P}{T E}$ & WCP = Wrimary Expense (Load Program) the previous year \\
\hline Working Capital Ratio & $T E=$ Total Expense \\
(WZF \&IZM 2017). & &
\end{tabular}

Source:World Zakat Forum and Indonesia Magnificence of Zakat (2018)

\section{LITERATURE REVIEW}

Harto. et al (2018) found that the ratio of program expenses, operating expense ratio, expense ratio and the efficiency of raising fundraising included in the fair category.Handayani et al (2017); Darmawati et al (2017); Musviyanti (2017) Nuraida (2012); Found that LAZ has good and adequate performance financial.Salim (2016) and Wahyuny (2015) found that financial performance amil zakat institutions rated totals 6.334 with a range equivalent to the value of 3 (quite good). From other perspective Hassan et al (2013) found that the accounting-based performance measures are more objective in the years where unstable economic conditions exist.

Palinggapo (2018); Lis (2018); Lulu (2016) showed that have good organizational accountability than the effectiveness of the output, input, and the outcomes and efficiency OPZ pretty good as well.In- country level, Wahab et al (2013) found that Total For Productivity (TFP) zakat institution in Malaysia increased at an average rate of 2.4 percent during the study period and mainly associated with the technical progress than the efficiency of the components. It is supported by Nurhasanah (2018) that performance of Amil Zakat (LAZ) and Amil Zakat Nasional (BAZNAS) that is accountable, transparent and professional. LAZ institution must have financial statements that are a reflection of good financial management, and to achieve maximum performance, PKPU pursuing a strategy of SO (Strength Opportunity) is to use a maximum of facilities and infrastructure to conduct training for prospective new mustahik willing and map (ready) for businesses (Nuraida: 2012). The formulation of strategies implemented concluded that distribute ZIS is not increased compared to the reception (Lestasi: 2010).

\section{RESEARCH METHODS}

The study population was BAZNAS Center and throughout LAZNAS in Indonesia. Samples were selected using purposive sampling technique. Purposive sampling is a sampling technique by researchers based on certain considerations predetermined (Sugiyono, 2008).

Table 7. Sample Selection Considerations

\begin{tabular}{lc}
\hline \multicolumn{1}{c}{ Information } & Total \\
\hline Zakat institution and verified BAZNAS SK Ministry of Religion and/or KEPPRES as the & 19 \\
Institute for National Zakat &
\end{tabular}




\begin{tabular}{lc}
\hline \multicolumn{1}{c}{ Information } & Total \\
\hline $\begin{array}{l}\text { National Zakat institution does not apply the transparency of the financial statements audited } \\
\text { publication }\end{array}$ & 12 \\
\hline National Zakat institution does not have audited financial statements in 2012-2017 & 4 \\
\hline Total sample research & $\mathbf{5}$ \\
\hline The period of analysis (2012 sd. 2017) & $\mathbf{6}$ \\
\hline The amount of research data during the study period & $\mathbf{3 0}$ \\
\hline
\end{tabular}

Source: Author

Based on the criteria, 5 National Zakat Organizations (LAZNAS) that meet the criteria for a sample is the BAZNAS Center and 4 LAZNAS namely Yatim Mandiri, Rumah Yatim Arrohman, Rumah Zakat, and Wallet Dhuafa. The type of data used to use primary and secondary data. Secondary data in this study is a type of panel data with a span of over 6 years ie from 2012 to 2017. Secondary data were obtained from the annual financial statements published BAZNAS and 4 National Zakat Organization for 6 years. Other data sources obtained from books and the Internet that provide information that supports research. The primary data obtained through interviews with the financial part BAZNAS related things needed in the data analysis.

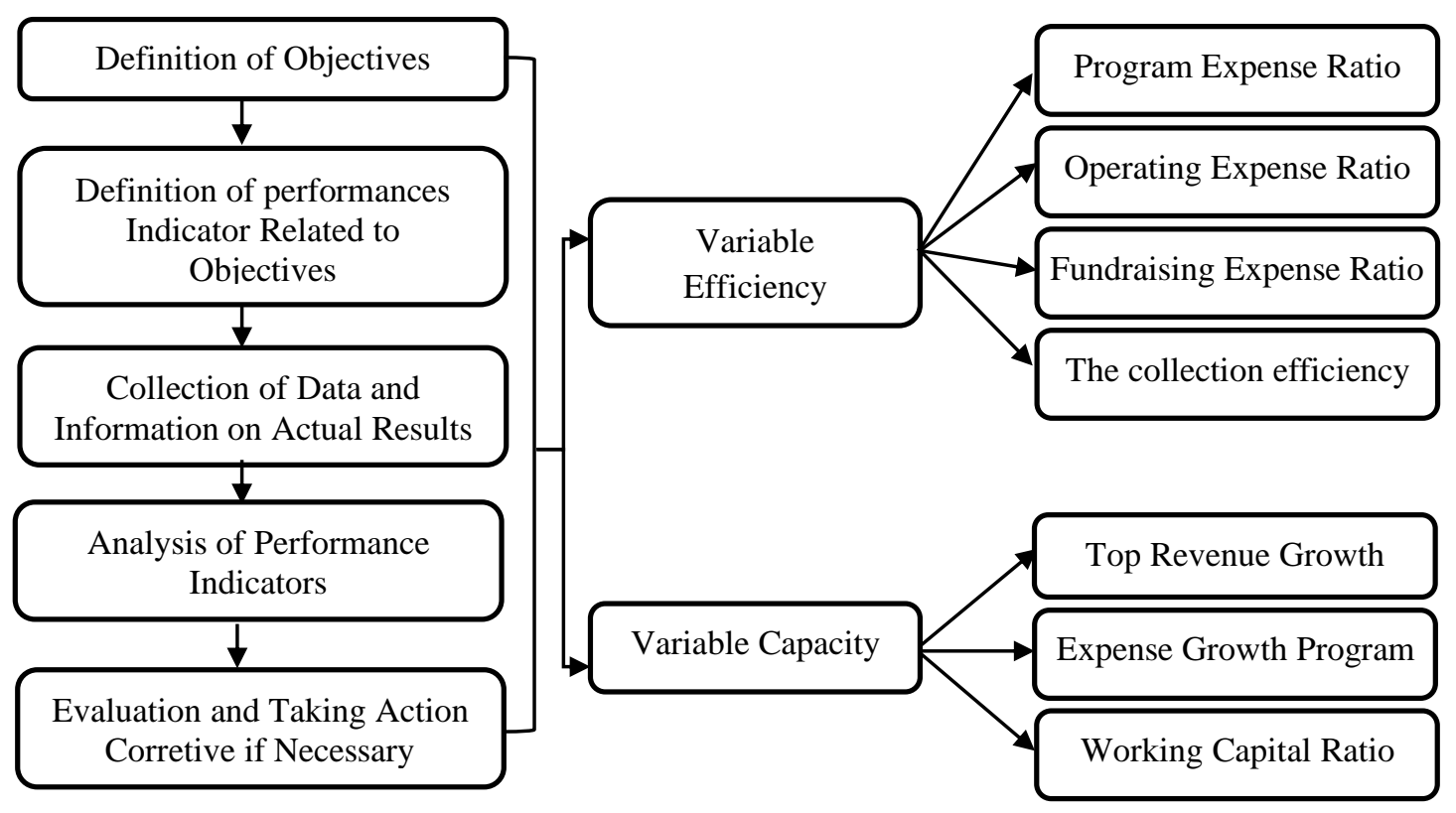

Figure 1. Data Fundrising Technique Performance Measurement Steps

\section{RESULT \& DISCUSSIONS}

The purpose of the analysis is narrowing and limiting to become regular data, as well as more than a means. Quantitative research related to the calculation to answer the problem formulation and submission of hypothesis (Sugiyono, 2013) model of data analysis using financial ratio analysis tool modification model of Ritchie \&Kolodinsky 
(2003) and the International Standard of Zakat Management (ISZM). The series of data analysis was performed with the following steps:

1. Data tabulation account through accounts in the financial statements to analyze financial performance ratios OPZ using technical analysis.

2. Calculate financial ratios. Accounts that have been tabulated to be calculated by using the formula of financial ratios modification Ritchie \& Kolodinsky and ISZM.

3. Discussion of the results of the analysis. This stage will present a discussion of the results of the calculation of financial ratios amil zakat institutions research sample. An explanation will be made with an indepth and interesting descriptive causal link on the results of calculating this ratio. The measurement scale for each ratio used in this study is a modification of the method mix ratios of research Ritchie \& Kolodinsky and ISZM

\section{Variable Efficiency}

\section{Program Expense Ratio}

Program Expenseratio measurement aims to see spending zakat institution for channeling the program of activities to mustahik. Indicator, the greater the ratio, the better the work program. The function of the work program zakat management institutions will get better as more and more spending program of activities aimed at empowering mustahik. Comparison of program expense ratio performed to assess the zakat institution which has the best fund distribution efficiency.

Table 8. Comparison Program Expense Ratio

\begin{tabular}{lccccccc}
\hline \multicolumn{7}{c}{ Program Expense Ratio } \\
\cline { 1 - 7 } \multicolumn{1}{c}{ Institution } & $\mathbf{2 0 1 2}$ & $\mathbf{2 0 1 3}$ & $\mathbf{2 0 1 4}$ & $\mathbf{2 0 1 5}$ & $\mathbf{2 0 1 6}$ & $\mathbf{2 0 1 7}$ & Average \\
\hline BAZNAS & $84 \%$ & $90 \%$ & $82 \%$ & $96 \%$ & $72 \%$ & $81 \%$ & $84 \%$ \\
\hline Rumah Yatim Arrahman & $78 \%$ & $89 \%$ & $104 \%$ & $85 \%$ & $90 \%$ & $10 \%$ & $89 \%$ \\
\hline Yayasan Yatim Mandiri & n.a & n.a & $94 \%$ & $65 \%$ & $57 \%$ & n.a & $72 \%$ \\
\hline Rumah Zakat & n.a & n.a & $72 \%$ & $89 \%$ & $89 \%$ & $90 \%$ & $85 \%$ \\
\hline Dompet Dhuafa & $92 \%$ & $90 \%$ & $94 \%$ & $96 \%$ & $100 \%$ & $100 \%$ & $95 \%$ \\
\hline
\end{tabular}

Table 8 shows the value of the load ratio is still an efficient program zakat institution because it is still above $70 \%$. It can be concluded that all relative zakat institution has run the main functions of institutions in mustahik empowerment. Dompet Dhuafa is also consistent in load management programs that increase every year and reach a value of $100 \%$ over the last 2 years. Based on the measurement results of zakat institution, Dompet Dhuafa have expense ratios of the most efficient program, which is an average of $95 \%$ over five years. 


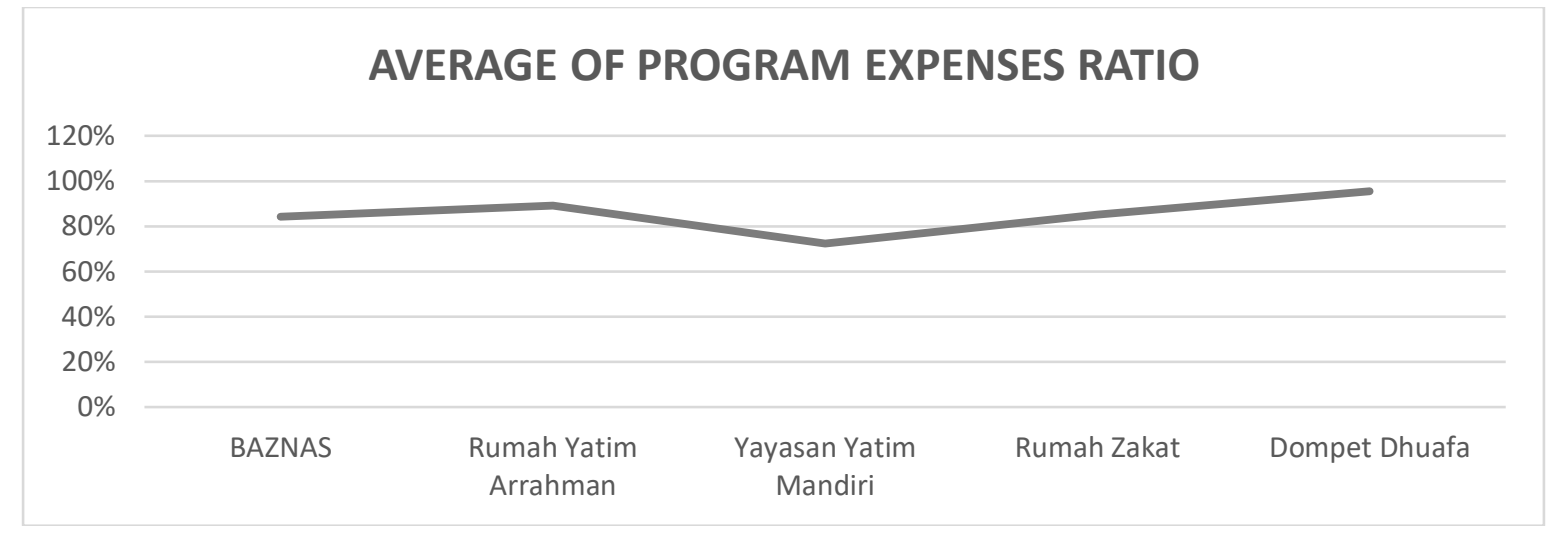

Figure 2. Average Program Expenses Ratio

Yayasan Yatim Mandiri is the zakat institution that has the lowest average for Program Expense Ratio. This is due to a decrease from the year 2014 to 2015. In calculating the expense ratio Yatim Mandiri Foundation Program can only be carried out for three years because of the unavailability of financial statements in 2012, 2013, 2016 and 2017. The average size of the Ratio of load program in Dompet Dhuafa due to an increase in each year. Although in 2013 had decreased by $2 \%$, but it managed to close in 2014, which increased by $4 \%$, followed by the subsequent years.Overall, each LAZ has a good performance in the use of the funds available for the benefit of the people. This is because the average minimum course load ratio is $72 \%$.

2. The ratio of operating expenses Measurements such as operating expenses required to look at the extent of zakat institution efficiency in managing its operating expenses to total expenses. The indicators, the smaller the result, the better, because it can be said that the institution of zakat has been efficiently managing its operational costs. Comparison of the ratio of operating expenses is done to see which charity institute the most efficient in controlling its operating expenses.

Table 9. Comparison of Operating Expense Ratio

\begin{tabular}{lccccccc}
\hline \multicolumn{7}{c}{ Operating Expense Ratio Comparison } \\
\hline \multicolumn{1}{c}{ Institution } & $\mathbf{2 0 1 2}$ & $\mathbf{2 0 1 3}$ & $\mathbf{2 0 1 4}$ & $\mathbf{2 0 1 5}$ & $\mathbf{2 0 1 6}$ & $\mathbf{2 0 1 7}$ & Average \\
\hline BAZNAS & $16 \%$ & $23 \%$ & $18 \%$ & $16 \%$ & $26 \%$ & $22 \%$ & $20 \%$ \\
\hline Rumah Yatim Arrahman & $22 \%$ & $11 \%$ & $17 \%$ & $15 \%$ & $10 \%$ & $10 \%$ & $15 \%$ \\
\hline Yayasan Yatim Mandiri & $\mathrm{na}$ & $\mathrm{Na}$ & $34 \%$ & $32 \%$ & $21 \%$ & na & $29 \%$ \\
\hline Rumah Zakat & $\mathrm{na}$ & $\mathrm{Na}$ & $14 \%$ & $11 \%$ & $10 \%$ & $10 \%$ & $11 \%$ \\
\hline Dompet Dhuafa & $8 \%$ & $10 \%$ & $8 \%$ & $5 \%$ & $8 \%$ & $10 \%$ & $8 \%$ \\
\hline
\end{tabular}


Measurement fund expense ratio is almost equal to the operating expenses to determine the burden of raising carried out is still within reasonable limits and following its function. The lower the value the better.

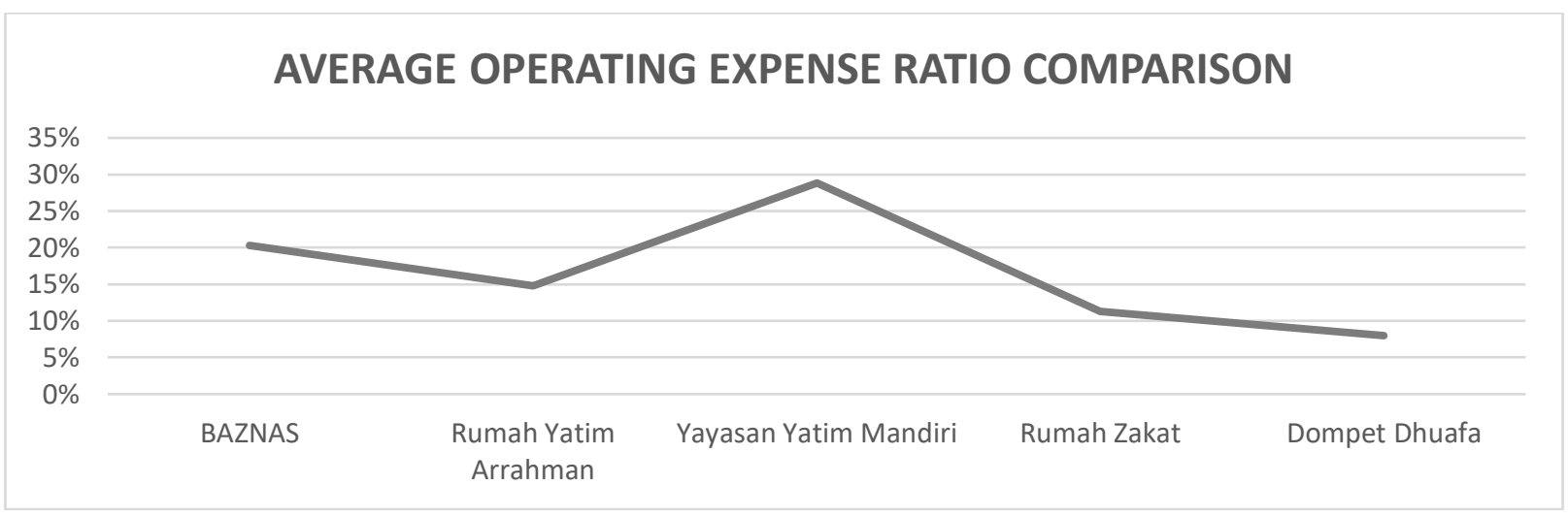

Figure 3. Average Operating Expense Ratio Comparison

The measurement results reflect all the operating expense ratio zakat institution has been efficient in arranging the proportion of expenditure in running operations. The operating costs remained within reasonable limits and following its functional costs. Institutions of zakat measured, Dompet Dhuafa has a ratio of operating expenses, the most efficient, which is an average of $8 \%$ for 5 years so Dompet Dhuafa is already quite efficient in operational use.

\section{Fundraising Expense Ratio}

Expense Ratio is The Fundrising costs incurred in the Fundrising of funds, such as advertising costs and socialization of one another year after year. A study of several institutions for five years to get the average acquisition expense ratio mobilization as follows:

Table 10. Fundraising Expense Ratio

\begin{tabular}{lccccccc}
\hline \multicolumn{7}{c}{ Fundraising Expense Ratio } \\
\hline \multicolumn{1}{c}{ Institution } & $\mathbf{2 0 1 2}$ & $\mathbf{2 0 1 3}$ & $\mathbf{2 0 1 4}$ & $\mathbf{2 0 1 5}$ & $\mathbf{2 0 1 6}$ & $\mathbf{2 0 1 7}$ & Average \\
\hline BAZNAS & $6 \%$ & $7 \%$ & $13 \%$ & $17 \%$ & $8 \%$ & $7 \%$ & $10 \%$ \\
\hline Rumah Yatim Arrahman & $0 \%$ & $7 \%$ & $12 \%$ & $9 \%$ & $4 \%$ & $7 \%$ & $7 \%$ \\
\hline Yayasan Yatim Mandiri & na & $\mathrm{Na}$ & $0 \%$ & $12 \%$ & $6 \%$ & na & $6 \%$ \\
\hline Rumah Zakat & na & $\mathrm{Na}$ & $2 \%$ & $2 \%$ & $2 \%$ & $1 \%$ & $2 \%$ \\
\hline Dompet Dhuafa & $12 \%$ & $12 \%$ & $8 \%$ & $5 \%$ & $9 \%$ & $10 \%$ & $9 \%$ \\
\hline
\end{tabular}

The results showed that BAZNAS as an institution that has an average expense ratio of the greatest accumulation of $10 \%$. LAZ lowest in raising expense ratio is Zakat House which is $2 \%$. 


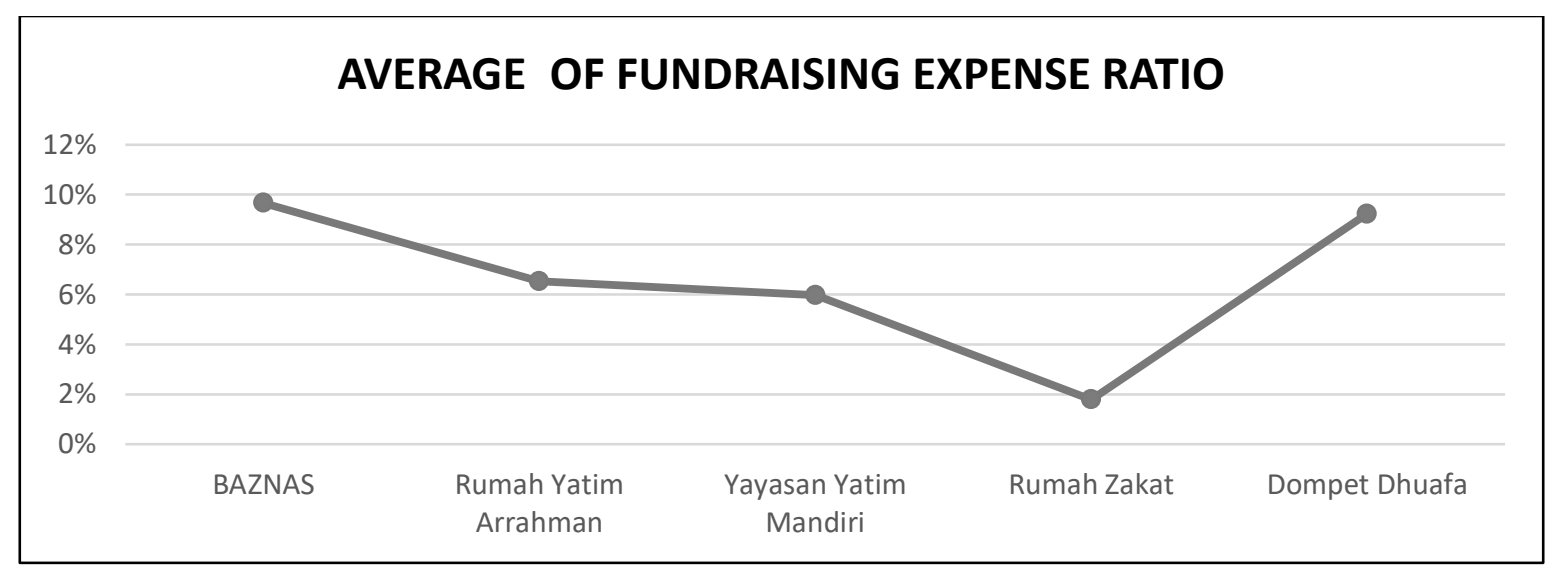

Figure 4. Average Expense Ratio Raising

The level of mobilization expense ratio depending on the amount of spending undertaken by LAZ in collecting funds in the community to be allocated to charity funds by LAZ as a mediator. The high average expense ratio of Fundrising to BAZNAS shows that the most cost BAZNAS to take unpaid charity by the public. LAZ as Rat-Average Expense Ratio The Fundrising but this is still considered normal due to very at point $10 \%$ and showed positive. It is indicated that BAZNAS and LAZ very cautious in issuing the funds thus managed to increase efficiency in the Fundrising.

\section{Fundraising Efficiency Ratio}

Raising efficiency ratio is obtained by dividing the total costs incurred to raise funds with a total contribution made by muzakki or funding from muzakki. A study of several institutions for five years earning achievements Average Efficiency Ratio of Fundrising as follows:

Table 11. Fundraising Efficiency Ratio

\begin{tabular}{lccccccc}
\hline \multicolumn{1}{c}{ Fundraising Efficiency Ratio } \\
\hline \multicolumn{1}{c}{ Institution } & $\mathbf{2 0 1 2}$ & $\mathbf{2 0 1 3}$ & $\mathbf{2 0 1 4}$ & $\mathbf{2 0 1 5}$ & $\mathbf{2 0 1 6}$ & $\mathbf{2 0 1 7}$ & Average \\
\hline BAZNAS & $6 \%$ & $7 \%$ & $13 \%$ & $13 \%$ & $8 \%$ & $8 \%$ & $9 \%$ \\
\hline Rumah Yatim Arrahman & $0 \%$ & $6 \%$ & $13 \%$ & $9 \%$ & $5 \%$ & $7 \%$ & $7 \%$ \\
\hline Yayasan Yatim Mandiri & n.a & $\mathrm{Na}$ & $0 \%$ & $8 \%$ & $6 \%$ & na & $4 \%$ \\
\hline Rumah Zakat & n.a & $\mathrm{Na}$ & $3 \%$ & $2 \%$ & $2 \%$ & $2 \%$ & $2 \%$ \\
\hline Dompet Dhuafa & $20 \%$ & $23 \%$ & $19 \%$ & $18 \%$ & $19 \%$ & $19 \%$ & $20 \%$ \\
\hline
\end{tabular}

The results showed that Dompet Dhuafa as an institution that has a rata-average expense ratio of the greatest accumulation of $20 \%$. LAZ lowest in raising expense ratio is Rumah Zakat which is $2 \%$. 


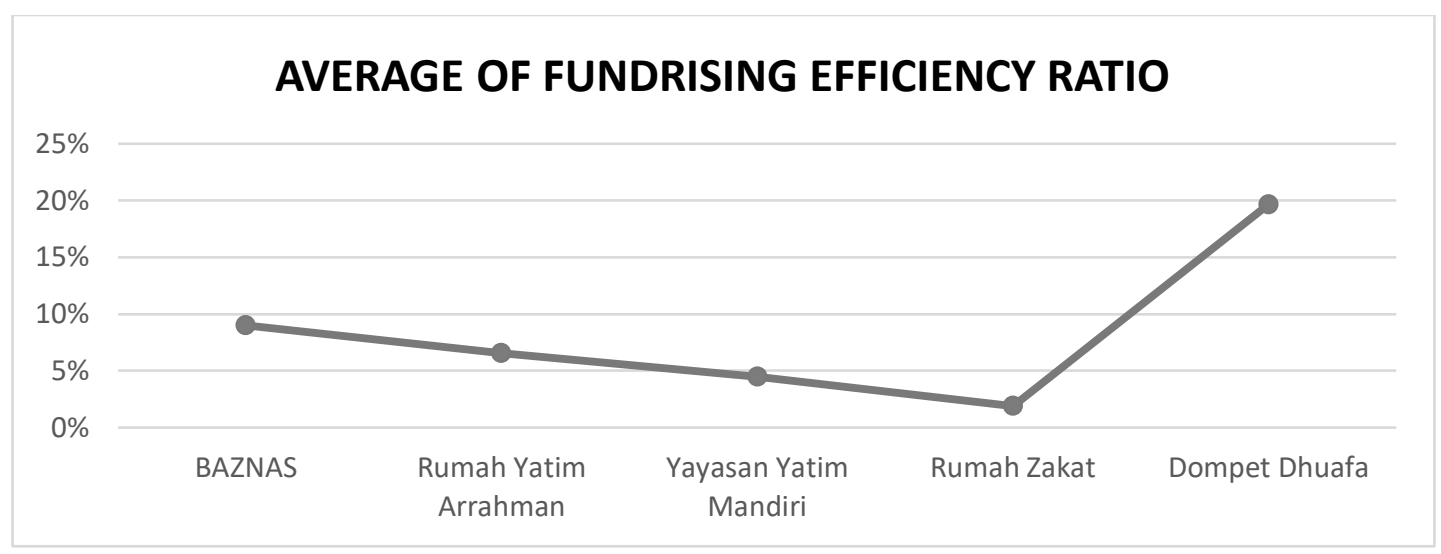

Figure 5. Average of Fundrising Efficiency Ratio

The average efficiency ratio of each LAZ has a positive value. This is because of the total contribution given by muzakki greater than the total cost of Fundrising incurred by LAZ to obtain funds from muzakki. The smaller average efficiency ratio that shows the performance of LAZ in raising funds better use. This is because the smaller the resulting average means less burden incurred by the accumulation of LAZ in collecting funds from muzakki. Based on the data that has been processed, shows the level of Fundrising efficiency at each LAZ well with an average below $10 \%$ except Dompet Dhuafa is $20 \%$. Although Dompet Dhuafa 20\% does not mean Dompet Dhuafa performance in achieving better Fundrising efficiency did not materialize.

\section{Variable Organizational Capacity}

1. Comparison of Top Revenue Growth Measurement capacity main revenue growth rate is to assess the ability of zakat institution in raising charity funds collected from the previous year. Measurement of the main revenue growth is seen from the number of charity fundraising during the year increased from the previous year or not through raising margin for the year with the previous year and compared with the previous year the number of accumulations. The greater the payoff would be even better. If the result of this ratio is minus, it can be interpreted that the Fundrising is done such charity organizations has decreased from the previous year.

Table 12. Comparison of Top Revenue Growth

\begin{tabular}{lcccccc}
\hline \multicolumn{7}{c}{ Top Revenue Growth } \\
\hline \multicolumn{1}{c}{ Institution } & $\mathbf{2 0 1 3}$ & $\mathbf{2 0 1 4}$ & $\mathbf{2 0 1 5}$ & $\mathbf{2 0 1 6}$ & $\mathbf{2 0 1 7}$ & Average \\
\hline BAZNAS & $15 \%$ & $43 \%$ & $14 \%$ & $19 \%$ & $38 \%$ & $26 \%$ \\
\hline Rumah Yatim Arrahman & $23 \%$ & $-12 \%$ & $20 \%$ & $23 \%$ & $20 \%$ & $15 \%$ \\
\hline Yayasan Yatim Mandiri & $\mathrm{na}$ & $\mathrm{Na}$ & $3 \%$ & $1 \%$ & $100 \%$ & $-32 \%$ \\
\hline Rumah Zakat & $\mathrm{na}$ & $\mathrm{Na}$ & $13 \%$ & $15 \%$ & $20 \%$ & $6 \%$ \\
\hline Dompet Dhuafa & $7 \%$ & $4 \%$ & $16 \%$ & $10 \%$ & $1 \%$ & $3 \%$ \\
\hline
\end{tabular}


From the calculation, all the agencies such as charity fundraising ratio experienced some differences. The most significant difference is the self orphans foundation that has decreased as seen from the average of its main revenue growth $-32 \%$. However, this is in contrast with other charity institutions that experienced major revenue growth with BAZNAS as a vanguard that is on average $26 \%$.

AVERAGE OF MAIN FUNDRISING

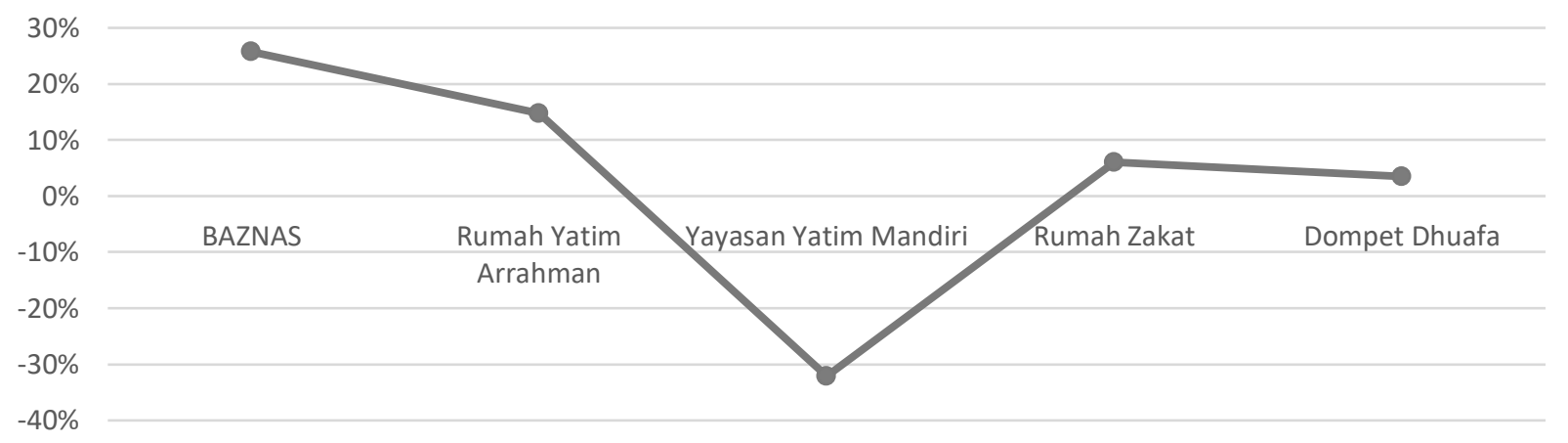

Figure 6. Average of Main Fundrising

Based on the diagram, BAZNAS have an average growth reception utam high compared to the fourth LAZ. Although in 2015 BAZNAS experienced a significant drop in at around $29 \%$, but this problem can be masked by an increase in the next year by $5 \%$, and even better in 2017 with an increase twice the percentage in 2016.
2. Growth Comparison Program Expenses

Measurement program load capacity growth rate seen from the greater growth of program expenses indicates that an increase in the distribution of the zakat institution to mustahik. Along with the increase in the Fundrising made zakat institutions should amount disbursed portfolio also increased.

Table 13. Comparison Expense Growth Program

\begin{tabular}{lcccccc}
\hline \multicolumn{7}{c}{ Expense Growth Program } \\
\hline \multicolumn{1}{c}{ Institution } & $\mathbf{2 0 1 3}$ & $\mathbf{2 0 1 4}$ & $\mathbf{2 0 1 5}$ & $\mathbf{2 0 1 6}$ & $\mathbf{2 0 1 7}$ & Average \\
\hline BAZNAS & $12 \%$ & $38 \%$ & $7 \%$ & $8 \%$ & $70 \%$ & $27 \%$ \\
\hline Rumah Yatim Arrahman & $32 \%$ & $20 \%$ & $-3 \%$ & $53 \%$ & $-88 \%$ & $3 \%$ \\
\hline Yayasan Yatim Mandiri & na & na & $6 \%$ & $24 \%$ & $100 \%$ & $15 \%$ \\
\hline Rumah Zakat & na & na & $30 \%$ & $-3 \%$ & $7 \%$ & $11 \%$ \\
\hline Dompet Dhuafa & $22 \%$ & $32 \%$ & $54 \%$ & $34 \%$ & $-5 \%$ & $14 \%$ \\
\hline
\end{tabular}

From the calculation, all the zakat institutions expense ratio is still relatively positive growth program, which is an average of $3-27 \%$ per 
year. This is a good indication for zakat institution seeks to channel funds optimally collected. This condition should occur on zakat institution. Measured from zakat institution, has a ratio of load growth BAZNAS best program, which is an average of $27 \%$ over five years.

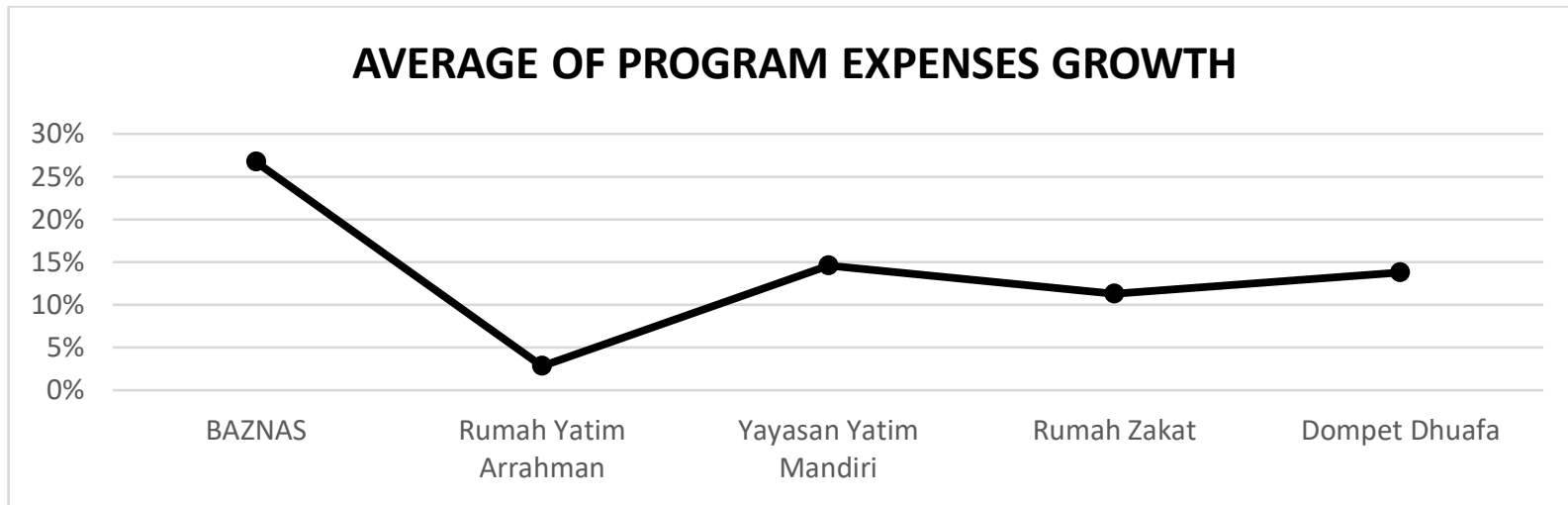

Figure 7. Average of Program Expenses Growth

The average growth in program expenses pioneered by BAZNAS with a percentage of $27 \%$. The average growth of high programming costs, following the revenue that has been received, but the main revenue growth should be greater than the growth in program expenses. In BAZNAS 2017 increased significantly, with a percentage of $70 \%$, while its main reception for my growth only amounted to $38 \%$.

\section{Capacity Measurement Working} Capital Ratio

Measurement capacity working capital ratio is used to see the extent to which the working capital is owned by OPZ able to working capital is owned by OPZ able to cover his expenses when such charity organizations do not generate new revenue. Working capital in the institution of zakat can be reflected in the balance of funds in the previous year then be the beginning balance of the current year the fund collectors. The bigger the better result indicating existing funds can cover the operating expenses of zakat institution.

Table 14. Comparison Working Capital Ratio

\begin{tabular}{lccccccc}
\hline \multicolumn{7}{c}{ Working Capital Ratio } \\
\hline \multicolumn{1}{c}{ Institution } & $\mathbf{2 0 1 2}$ & $\mathbf{2 0 1 3}$ & $\mathbf{2 0 1 4}$ & $\mathbf{2 0 1 5}$ & $\mathbf{2 0 1 6}$ & $\mathbf{2 0 1 7}$ & Average \\
\hline BAZNAS & $34 \%$ & $12 \%$ & $1 \%$ & $2 \%$ & $3 \%$ & $4 \%$ & $9 \%$ \\
\hline Rumah Yatim Arrahman & $5 \%$ & $38 \%$ & $1 \%$ & $2 \%$ & $2 \%$ & $8 \%$ & $9 \%$ \\
\hline Yayasan Yatim Mandiri & $\mathrm{na}$ & $\mathrm{na}$ & $32 \%$ & $13 \%$ & $27 \%$ & $\mathrm{na}$ & $24 \%$ \\
\hline Rumah Zakat & $\mathrm{na}$ & $\mathrm{na}$ & $27 \%$ & $33 \%$ & $24 \%$ & $13 \%$ & $24 \%$ \\
\hline Dompet Dhuafa & $37 \%$ & $31 \%$ & $0 \%$ & $0 \%$ & $0 \%$ & $0 \%$ & $11 \%$ \\
\hline
\end{tabular}


From the calculation, all the charity organizations working capital ratio is still relatively positive. This indicates that the zakat institutions are still able to cover its operational expenses with amyl existing fund balance without new revenue generating. Zakat institutions are measured, the average working capital Rumah Zakat and Yayasan Yatim Mandiri is the highest average is $24 \%$, but both have different numbers of years in calculatition average, namely Rumah Zakat calculations for four years, while the Yayasan Yatim Mandiri independently by five years.

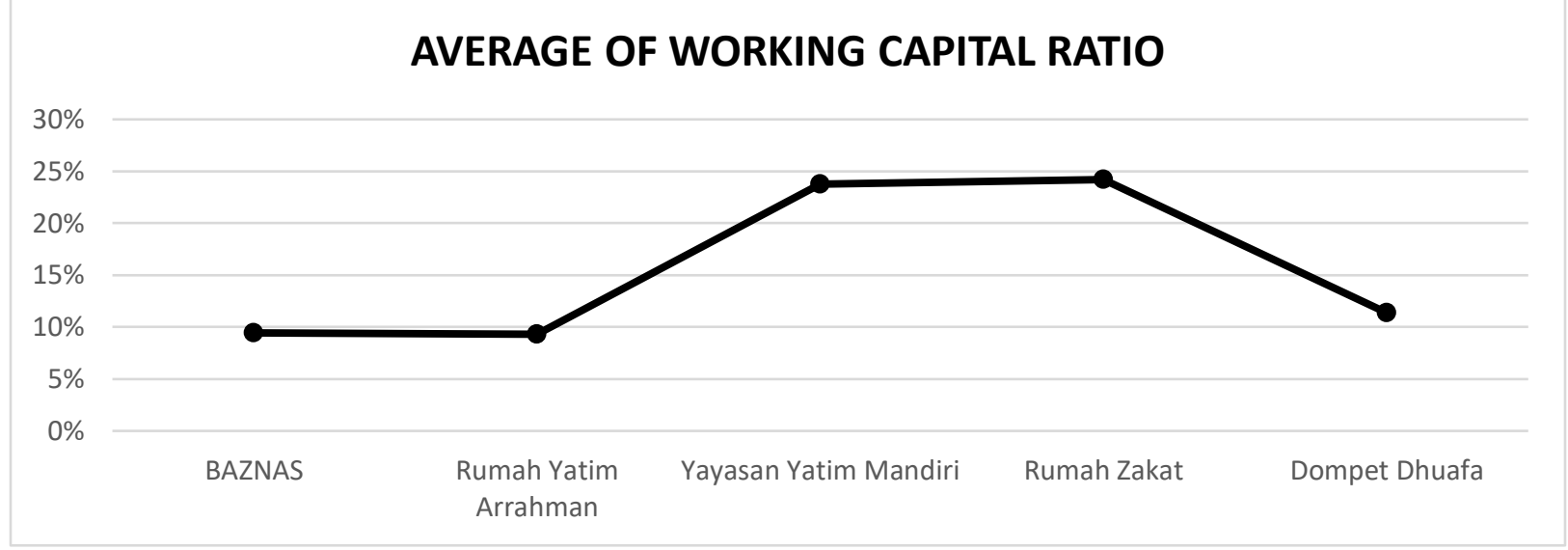

Figure 8. Average of Working Capital Ratio

\section{Summary of Performance Ratio}

Summary of Performance consist of Comparison of Variable efficiency and Comparison of Variable Capacity. Comparison of Variable efficiency based on Mahsun's opinion. According to Mahsun (2009:187), Efficiency Criteria are:
1. If a value of less than $100 \%$ ( $x$ $<100 \%)$ is obtained, it means efficient.

2. If the value is equal to $100 \%(\mathrm{x}=$ $100 \%)$, it means that the efficiency is balanced.

3. If a value of more than $100 \%$ ( $x>$ $100 \%$ ) is obtained, it means that it is inefficient.

Table 15. Comparison of Variable efficiency

\begin{tabular}{|c|c|c|c|c|c|c|c|}
\hline \multirow[b]{2}{*}{ Institution } & \multicolumn{5}{|c|}{ Comparison of Variable efficiency } & \multirow[b]{2}{*}{ Rank } & \multirow[b]{2}{*}{ Status } \\
\hline & $\begin{array}{c}\text { Program } \\
\text { Expense } \\
\text { Ratio }\end{array}$ & $\begin{array}{c}\text { Expense } \\
\text { Growth } \\
\text { Program }\end{array}$ & $\begin{array}{c}\text { Fundraising } \\
\text { Expense } \\
\text { Ratio }\end{array}$ & $\begin{array}{c}\text { The } \\
\text { Fundrising } \\
\text { Efficiency } \\
\text { Ratio }\end{array}$ & Average & & \\
\hline BAZNAS & $84 \%$ & $20 \%$ & $10 \%$ & $9 \%$ & $31 \%$ & 4 & Efficient \\
\hline $\begin{array}{l}\text { Rumah Yatim } \\
\text { Arrahman }\end{array}$ & $89 \%$ & $15 \%$ & $7 \%$ & $7 \%$ & $30 \%$ & 3 & Efficient \\
\hline $\begin{array}{l}\text { Yayasan Yatim } \\
\text { Mandiri }\end{array}$ & $72 \%$ & $29 \%$ & $6 \%$ & $4 \%$ & $28 \%$ & 2 & Efficient \\
\hline Rumah Zakat & $85 \%$ & $11 \%$ & $2 \%$ & $2 \%$ & $25 \%$ & 1 & Efficient \\
\hline Dompet dhuafa & $95 \%$ & $8 \%$ & $9 \%$ & $20 \%$ & $33 \%$ & 5 & Efficient \\
\hline
\end{tabular}

Based on the data and the indicators, it is describing if all of institution have an efecient status. 


\section{Comparison of Variable Capacity} According to Mahsun (2009: 187-188) the effectiveness criteria are:

1. If a value of less than $100 \%$ (x $<100 \%$ ) is obtained, it means that it is not effective.
2. If the value is equal to $100 \%(\mathrm{x}=$ $100 \%$ ), it means that the effectiveness is balanced.

3. If a value of more than $100 \%$ ( $x>$ $100 \%)$ is obtained, it means it is effective.

Table 16. Percentage of Financial Performance

\begin{tabular}{cc}
\hline $\begin{array}{c}\text { Percentage of Financial } \\
\text { Performance }\end{array}$ & Criteria \\
\hline Above $100 \%$ & Very Effective \\
\hline $90 \%-100 \%$ & Effective \\
\hline $80 \%-90 \%$ & Effective \\
\hline $60 \%-80 \%$ & Less Effective \\
\hline Less than $60 \%$ & Not effective \\
\hline
\end{tabular}

Source: Decree of the Minister of Home Affairs Number 690,900,327 of 1996 :

Table 17. Comparison of Variable Effectivity

\begin{tabular}{|c|c|c|c|c|c|c|}
\hline \multirow[b]{2}{*}{ Institution } & \multicolumn{5}{|c|}{ Comparison of Variable effectivity } & \multirow[b]{2}{*}{ Status } \\
\hline & $\begin{array}{l}\text { The Main } \\
\text { Revenue } \\
\text { Growth }\end{array}$ & $\begin{array}{l}\text { Expense } \\
\text { Growth } \\
\text { Program }\end{array}$ & $\begin{array}{c}\text { Working } \\
\text { Capital } \\
\text { Capacity } \\
\text { Ratio }\end{array}$ & Average & Rank & \\
\hline BAZNAS & $26 \%$ & $27 \%$ & $9 \%$ & $62 \%$ & 1 & Less Effective \\
\hline Rumah Yatim Arrahman & $15 \%$ & $3 \%$ & $9 \%$ & $27 \%$ & 4 & Not Effective \\
\hline Yayasan Yatim Mandiri & $-32 \%$ & $15 \%$ & $24 \%$ & $7 \%$ & 5 & Not Effective \\
\hline Rumah Zakat & $6 \%$ & $11 \%$ & $24 \%$ & $41 \%$ & 2 & Not Effective \\
\hline Dompet dhuafa & $3 \%$ & $14 \%$ & $11 \%$ & $28 \%$ & 3 & Not Effective \\
\hline
\end{tabular}

Based on both of the results, BAZNAS be the first classment in each category. That happened beause BAZNAS always publish their financial report and the structure of the financial report based on ISZM. If all institution like BAZNAS and LAZNAS in harmony to make the roles about the account of financial report, it could be easier than before. The other side, an auditor have not to clasificate but do audit directly. As the example is the negative impact of institution doesn't publish the financial repost are reduce the brand image of the institution. Rumah Zakat as the institution doesn't publish the financial report in year of year type.

\section{CONCLUSION}

The results of this study concluded that the financial performance BAZNAS, Rumah Yatim Arrahman LAZ, LAZ Yatim Mandiri Foundation, Rumah Zakat LAZ and LAZ 
Dompet Dhuafa during the period 20122017 assessed based on the ratio of modification (mix method) between Ritchie and Kolodinsky with the International Standard of Zakat Management ( ISZM) based on efficiency, there are four variables that have examined the ratio expense ratio Program, operating expense ratio, ratio of load accumulation, Fundrising efficiency ratio average each BAZNAS and LAZ has a positive value and quite effective as well as efficient. Later on, there are three organizational capacity variable ratio of the main revenue growth, growth in program expenses and working capital ratio shows that the relative growth BAZNAS and LAZ positive and good.

\section{RECOMMENDATIONS}

1. There is still a marked gap in performance system with strategy and missions. The challenge is to understand what alignment of mission and strategy look like in social sectors and how to design good performance and control systems to enable and support the goals.

2. Current innovations in social sectors offer adaptive learning and participatory governance and social movements to improve social performance and give contributions in practice and theories. Create, organize, and align organizational architecture zakat and road map plan short, medium, and long. The budget is prepared with the theme of priorities for allocating funds each year.

3. Strengthening the synergy between zakat management organizations through direct collaboration, the replication program agencies, and multi-stakeholder synergies and synergy between non-charity organizations in both the public and other sectors.Integration of the database on each organization zakat includes features such a comprehensive work program, the data mustahik and more in a single system to improve accountability and transparency.

4. An independent team zakat supervisory board to monitor and provide feedback.

\section{REFERENCES}

Al-Quran Translations. 2015. Department of Religious Affairs. Bandung: CV Darus. Sunnah.

Aldrick, T. 2009. Benchmarking the fundraising performance of UK Charities, International Journal of Nonprofit and Voluntary Sector Marketing, 14: 353-364.

Arimaviciute $\quad$ M. 2005. Viesojosectoriausinstitucijustrateginis valdymas: vadovelis. Vilnius. P-72-79

Atalay, Bedia, Gungormus, Ali Haydar, and Boyar, Ender. 2017. Ratio Analysis in the Measurement of Financial Performance of Non-Profit Organizations (Non-Governmental Organizations). Journal of Business Research Turk.

Badan Amil Zakat Nasional. (2017). The Audited Financial Statements Year Ended December 31, 2015 and 2016. Jakarta: Badan Amil Zakat Nasional.

Badan Amil Zakat Nasional. (2018). The Audited Financial Statements Year Ended December 31, 2016 and 2017. Jakarta: Badan Amil Zakat Nasional.

Bahri, ES, Romantin, M., \& Lopez, AT (2017). Zakat Organization Financial Performance Analysis (Case Study: National Zakat Agency). Shield: Islamic Banking and Finance Journal, 1 (2), 96-116.

Balabonienen, Ingrida and Vecerskienen, Giedre. 2015.The Aspects of Performance Measurement in the Public Sector Organization, Procedia Social and Behavioral Sciences 213 (314-320). 
Carman, J. (2007). Evaluation practice among community-based organizations: Research into reality. American Journal of Evaluation, 28 (1), pp. 60-75.

Center of for Strategic Studies (Puskas) BAZNAS. (2016). Outlook Zakat Indonesia 2017. Jakarta: Center for Strategic Studies BAZNAS.

Daft, Richard L., 2012. Organization Theory and Design 11th Edition, SouthWestern College Pub. Cincimanti, Ohio.USA

Decree of the Minister of Religious Affairs of the Republic of Indonesia No. 333 the Year 2015.Tentang Guidelines for Licensed Establishment of Zakat. 2015.

Fine, T., and Snyder, L. (1999). What is the difference between performance and benchmarking? Public Management, 81 (1), pp. 24-25.

Gill, M., RJ, and Reissing E. Flynn, 2005. The Governance Self-Assessment Checklist: An instrumentfor assessing board effectiveness, Nonprofit Management, and Leadership, 15: 271-294.

Hadinata, I., \&Manurung, AH (tt). Application of Data Envelopment Analysis (DEA) for Measuring Performance Efficiency Equity Fund. 2.

Herman RD \& Renz, DO 1999. Thesis on nonprofit organizational effectiveness. Nonprofit and Voluntary Sector Quarterly, 28, 107-125. Fine, T., and Snyder, L. (1999). What is the difference between performance and benchmarking? Public Management, 81 (1), pp. 24-25.

IT and Reporting Bureau of the National Zakat Board. (2017). Statistics of the National Zakat 2016. Jakarta: MIS and Reporting Section Badan Amil Zakat Nasional.
Jones, Gareth R., 2013. Organizational Theory, Design, and Change, Seventh edition, Pearson Edition Limited, Edinburgh Gate Harlow Essex CM20 2JE, England.

Kanter, RM, and Summers, D. 1987. Doing well while doing good, In WW Powell (Ed). The nonprofit sector: A research handbook, New Haven, CT: Yale University Press.

Kendall, J. and Knapp, M. 2000. Measuring the performance of voluntary organizations, Public Management Review, 2: 1, 105-132.

Kaplan, RS, \& Norton, DP (1992). The Balanced Scorecard-Measures that Drive Performance. Harvard Business Review, 71.

Lester, A. (2015). Financial Performance Efficiency Regional Amil Zakat Agency (BAZDA): Approach Data Envelopment Analysis (DEA). JESP: Journal of Economics and Development Studies, 16 (2), 177-187.

Law of the Republic of Indonesia No.23 of 2011. (2011). On Zakat Management. Jakarta: House of Representatives (DPR).

Muftasany, H. (2015, November 27). WZF Fueling Improved Management of Zakat in the World. Republika newspaper.

National Zakat Board Regulation No. 03 of 2014 (2014). Organization and the Governing Board and the Provincial National Zakat Board National Zakat District /City.

Nisvianti, \&Andoko, W. (2013). Comparative Study of Financial Performance Bank Syariah Mandiri (Islamic Banking) with Bank Mandiri (Conventional Banking). Assets light, $3(2), 115$.

Nurhasanah, S., \& Lopez, D. (2017). Performance efficiency BAZNAS Bogor and Sukabumi: Data 
Envelopment Analysis Approach. Journal of Accounting and Islamic Finance, 5 (2), 105-120.

Parisi, SA (2017). Level of Efficiency and Productivity Institute of Zakat in Indonesia. Essence: Journal of Business and Management, 7 (1), 6372.

PEBS FEUI \& IMZ. (2010). Architecture initiated Zakat Indonesia: Towards Synergies Government and Civil Society in the National Zakat Management. Jakarta: IMZ.

Polese, Francesco et.all. 2017.Performance Evaluation and Measurement in Public Organizations: A Systematic Literature Review, International Journal of Business Administration Vol 8, No. 1: 2017.

Ramadan, Mohammed Abo, and Borgonovi, Elio. 2015.Performance Measurement and Management in the NonGovernmental Organizations, Journal of Business and Management Vol 17, Issue 2.Ver.III. PP. 70-76.

Ritchie, WJ \& Kolodinsky, RW 2003. Nonprofit organization financial performance measurement: An evaluation of new and existing financial performance measures, Nonprofit Management \& Leadership, 13, 367-381. Fine, T., and Snyder, L. (1999). What is the difference between performance and benchmarking? Public Management, 81 (1), pp. 24-25.

Ritchie, William $J$ and Kolodinsky, Robert.W. (2003). Nonprofit Organization Financial Performance Measure: An Evaluation of New and Existing Financial. Nonprofit Management \& Leadership, vol.13, no.4, Summer 2003

Smalsky V. 2010. Viesasivaldymas: Vilnius: MykoloRiomerioUniversitetas.
Sugiyono, PD (2008). Quantitative Research Methods, Qualitative and R \& D. Bandung: PT. Alfabeta.

Sujarweni, VW (2017). Financial Statement Analysis Theory, Applications, and Research. Yogyakarta: New Library Press.

Teelken, C. (2008). The intricate implementation of performance measurement systems: Exploring developments in professionalservice organization in the Dutch non-profit sector. International Review of Administrative Sciences, 74 (4), pp. 615-635.

Triyuwono, Iwan. 2012. Islamic Accounting: Perspectives, Methodology, and Theory. Second Edition. PT. King GrafindoPersada.Jakarta

Wibisono, Y. (2016). Opportunities and Challenges of Management. National Seminar 2016. Zakat Depok.

Widodo, H., \& Kustiawan, T. (2001). Accounting and Financial Management for Zakat Management Organization. Tangerang: Zakat Management Institute.

World Zakat Forum and Indonesia Magnificence of Zakat. (2017). In Juwaini, et.al (Editor), International Standard of Zakat Management ISZM: 2017. Jaksarta: IMZ Publishing.

Yasin, A. et. al (2017). Potential and Actual Zakat Fund Indonesia. Al-Uqud: Journal of Islamic Economics, 1 (1), 14-26.

Zakat Forum. (2012). Blueprint of Development of Zakat Indonesia 20112025: Free Future Zakat Indonesia. Jakarta: Forum Zakat (FOZ).

Peny Cahaya Azwari 
State Islamic University of Raden Fatah Palembang

penycahayaazwari_uin@radenfatah.ac.id

Khairul Rijal (Corresponding Author)

International Islamic University of Malaysia (IIUM)

khairulrijal1702@gmail.com

Nurfala Safitri

State Islamic University of Raden Fatah

Palembang

nurfalasafitri170@gmail.com

Rambo Saputra

State Islamic University of Raden Fatah

Palembang

saputrarambo96@yahoo.com 